\title{
Pentagamaboronon-0-Sorbitol Induces Apoptosis through Elevation of Reactive Oxygen Species in Triple Negative Breast Cancer Cells
}

\author{
Ratna Dwi Ramadani ${ }^{1}$, Rohmad Yudi Utomo ${ }^{1,2}$, Adam Hermawan ${ }^{1,3}$, Edy Meiyanto ${ }^{1,3^{*}}$ \\ ${ }^{1}$ Cancer Chemoprevention Research Center (CCRC), Faculty of Pharmacy, Universitas Gadjah Mada, \\ Sekip Utara Yogyakarta 55281 \\ ${ }^{2}$ Laboratory of Medicinal Chemistry, Department of Pharmaceutical Chemistry, Faculty of Pharmacy, \\ Universitas Gadjah Mada, Sekip Utara Yogyakarta 55281 \\ ${ }^{3}$ Laboratory of Macromolecular Engineering, Department of Pharmaceutical Chemistry, Faculty of Pharmacy, \\ Universitas Gadjah Mada, Sekip Utara Yogyakarta 55281
}

\begin{abstract}
Breast cancer is the most common type of cancer causing mortality for women due to metastasis. More than $50 \%$ of breast cancer patients are suffered lung metastases. One strategy to target the cancerous cell is Boron Neutron Captured Therapy (BNCT) which showed high affinity toward cancer cells and reported to have anti-proliferative as well as anti-metastatic activities. Pentagamaboronon-0 (PGB-0) is a curcumin analogue substance which had reported to exert anticancer activities against Her-2 expressing as well as triple negative breast cancer cells. Despite its great potency as BNCT agent candidate, this compound also exerted several anticancer properties. Complex formation of this substance with sorbitol was achieved to improve the solubility and maximize compound's delivery to the target cells. This study aimed to investigate the ability of Pentagamaboronon-0-Sorbitol (PGB-0-So) to modulate cell cycle and induce apoptosis especially through the mechanisms of reactive oxygen species (ROS) modulation. The 3-(4,5-dimethylthiazzol-2yl)-2,5diphenyltetrazolium (MTT) cytotoxicity assay of PGB-0-So against 4T1 breast cancer cell line were found to exert potential effect in dose-dependent manner with lethal concentration $\left(\mathrm{IC}_{50}\right)$ values of $39 \mu \mathrm{M}$. The cytotoxicity of PGB-0-So complex was found to be increased considerably compared with that of PGB-0. Cell cycle modulation identified using propidium iodide (PI) staining showed cell accumulation in S phase following treatment with PGB-0-So. Apoptosis induction assay analyzed using flowcytometer with Annexin $\mathrm{V}$ and PI staining on its $\mathrm{IC}_{50}$ dose was found to induce programmed cell death (apoptosis). The sub-IC $\mathrm{C}_{50}$ treatment of this compound was also improved the cellular ROS level which also took role in apoptosis induction. These findings suggest that PGB-0-So is potential as an anticancer agent.
\end{abstract}

Keywords: Curcumin analogue, PGB-0-So, Anticancer, 4T1 cell line, ROS modulation.

\section{INTRODUCTION}

Breast cancer is the most common type of cancer causing mortality for women which is still poorly identified (Xiao, et al., 2018). In 2012, there were registered 1.67 million new cases of breast cancer mortality in women by 198,000 in all over the world (Ferlay, et al., 2015). It was estimated

Submitted: December 16, 2020

Revised: March 16, 2021

Accepted: March 17, 2021

*Corresponding author: edy_meiyanto@ugm.ac.id 
that $20-25 \%$ of all patients with breast cancer found has Human Epidermal Growth Factor Receptor 2 (HER2) amplification (Mendes, et al., 2015) and approximately $10-15 \%$ of them was known to be triple negative breast cancer (TNBC) (Dawood, 2010). These breast cancer subtypes are positivemetastatic breast cancer (MBC) which have worse prognosis leading to aggressive disease. Metastatic pattern investigation on breast cancer patients showed $57-77 \%$ of them suffered lung metastases (Lee, 1983). Moreover, failure of metastasis prevention primarily caused mortality in breast cancer (Redig and McAllister, 2013).

Curcumin analogues based on benzylidine cyclopentanone backbone such as Pentagamavunon-0(PGV-0) and Pentagamavunon-1 (PGV-1) exerted potent cytotoxic and anti-metastatic activities toward several types of breast cancer cells (Meiyanto, et al., 2014; Putri, et al., 2016). Pentagamaboronon-0 (PGB-0) is a novel curcumin analogue based on benzylidine cyclopentanone developed by Faculty of Pharmacy, Universitas Gadjah Mada. Cytotoxicity of PGB-0 toward HER2 positive breast cancer had been determined and showed to decrease HER2 expression (Utomo, et al., 2017). PGB-0 also performed anti-metastatic activity toward triple negative breast cancer cells (Kusumastuti, et al., 2019). Since this compound showed poor solubility in water, complexation PGB-0 with polyol sugar Sorbitol was done to optimize the potency of this substance as anticancer agent (Chen, et al., 2013; Dash, Srinivas and Babu, 2019). PGB-0-So had reported to inhibit the activity of Matrix Metalloproteinase 9 (MMP-9) which plays role in tumor invasion in several breast cancer cells (Qodria, et al., 2018; Ramadani, et al., 2018).

Reactive oxygen species (ROS) showed an interestingly important role especially in biological processes (Covarrubias, et al., 2008; Abdal Dayem, et al., 2017). Under normal conditions, the regulation of ROS level is conducted steadily to prevent cells from damages through the activation of cell survival signaling cascade involving mitogen-activated protein kinase/extracellular signal-regulated protein kinases 1/2 (MAPK/ERK1/2), p38, c-Jun N-terminal kinase (JNK), and phosphoinositide3-kinase/ protein kinase B (PI3K/Akt) (Simon, et al., 2000; Liou, et al., 2010; Son, et al., 2011; Schattenberg, et al., 2014; Aggarwal, et al., 2019). Moreover, large amount of ROS molecules inside the cell could also trigger oxidative stress which later would regulate cell damage through the mechanisms of cell death induction (He, et al., 2017). Previous researches reported that the elevation of ROS level was detected from many kind of cancers. At high concentrations, ROS can cause cancer cell apoptosis. Therefore, in this study we aim to investigate the potency of Pentagamaboronon-0Sorbitol (PGB-0-So) to induce apoptosis towards triple negative breast cancer cells.

\section{MATERIAL AND METHODS}

\section{Chemicals}

The PGB-0-So complex was prepared according to (Watanabe, et al., 2016) using the PGB-0 and Sorbitol compounds in the ratio $1: 8$. The result of the complexation was in the form of $5 \mathrm{~mL}$ of clear yellow PGB-0-So solution then freeze dry and stored at $4^{\circ} \mathrm{C}$ for further use. The Freeze dried PGB-0-So was dissolved in 5 $\mathrm{mL} \mathrm{ddH2O} \mathrm{and} \mathrm{filtered} \mathrm{using} \mathrm{a} 0.22 \mu \mathrm{m}$ syringe filter. The filter results were then analyzed using a spectrophotometer to determine the concentration of the PGB-0-So compound and the compound could be used for testing.

\section{Cell Culture}

The 4T1 cell line were kindly given by Prof. Dr. Mashashi Kawaichi (NAIST, Japan) and were cultured in $\mathrm{CO}_{2}$ incubator $\left(37^{\circ} \mathrm{C}\right)$ with Dulbecco's Modified Eagle Medium (Gibco, New York, USA) suplemented with 10\% Fetal Bovine Serum (FBS) (Sigma, St. Louis, Missouri, USA), $150 \mu / \mathrm{mL}$ Penicillin and $150 \mu \mathrm{g} / \mathrm{mL}$ Streptomicin (Gibco), and $1.25 \mu \mathrm{g} / \mathrm{mL}$ Fungizone (Amphotericin B) (Sigma). 
Subculture was performed using Trypsin-EDTA (Gibco) for cell detachment. Samples used were synthesized PGB-0-So, as previously described.

\section{3 - (4,5 - dimethylthiazzol-2yl) - 2, 5 -} diphenyltetrazolium (MTT) Cytotoxicity Assay

Cytotoxicity assay of was performed using MTT assay adapted from Utomo, et al., 2017. The $2 \times 10^{3}$ of $4 \mathrm{~T} 1$ cells were seeded into each well on 96 well-plate. On the next day, cells were treated with PGB-0-So by the series of concentrations $(5,10,15$, $25,50,75$, and $100 \mu \mathrm{M}$ ) for $24 \mathrm{~h}$. Cells were added with $100 \mathrm{uL}$ of $0.5 \mathrm{mg} / \mathrm{mL}$ MTT reagent (Biovision, California, USA) and incubated for 2-4 h. At the end of incubation period, SDS stopper solution containing $0,01 \mathrm{~N} \mathrm{HCl}$ was added to each well. The absorbance was measured by ELISA reader at $\lambda 595 \mathrm{~nm}$. Cells were added with $100 \mathrm{uL}$ of 0.5 $\mathrm{mg} / \mathrm{mL}$ MTT reagent and incubated for 2-4 h. At the end of incubation period, SDS stopper solution containing $0,01 \mathrm{~N} \mathrm{HCl}$ was added to each well. The absorbance was measured by ELISA reader at $\lambda 595$ $\mathrm{nm}$. In combination cytotoxic assay, combination index value was examined using CompuSyn ${ }^{\circledR}$ software and the category was defined based on Patrick Reynolds and Maurer (2005). The potential application in combination therapy was analyzed using the combinatorial index method (CI) based on Reynold and Maurer (2005).

\section{Cell Cycle Assay}

Cell cycle assay of this research was performed using flowcytometer according to Amalina, et al., 2017. A total of $2 \times 10^{5}$ cells $/ \mathrm{mL}$ of 4T1 cells were seeded in each well of 6-well plate with DMEM medium (10\% FBS, $1.5 \%$ penicillinstreptomycin, $0.5 \%$ fungizone) and incubated in an incubator $\left(5 \% \mathrm{CO}_{2}, 37^{\circ} \mathrm{C}\right)$ for $24 \mathrm{~h}$. Furthermore, cells were treated with PGB-0-So compound at concentrations of 40 and $60 \mu \mathrm{M}$ for $24 \mathrm{~h}$. On the next day, cell harvesting and centrifugation were carried out to obtain cell pellets. Cells were fixed with $70 \%$ ethanol for 30 minutes and stained with propidium iodide (PI) (400 $\mu$ PI reagent containing
$1 \mathrm{mg} / \mathrm{mL}$ PI, $10 \mathrm{mg} / \mathrm{mL}$ RNAse and $0.1 \%(\mathrm{v} / \mathrm{v})$ Triton-X 100) to read after 30 minutes using the FACS Calibur flowsitometer.

\section{Apoptosis Assay}

Apoptosis assay was conducted by Annexin V-FITC/PI staining flowcytometry according to Putri, et al., 2016. The $2 \times 10^{5} 4 \mathrm{~T} 1$ cells were seeded in each well of 6-well plate and treated with the different concentrations of PGB-0-So for $24 \mathrm{~h}$. Cells were harvested using trypsin-EDTA, collected, and stained Annexin-V-FLUOS staining kit (Roche, Zhangjian Hi-Tech Park, Shanghai, China) consisting of $500 \mathrm{~mL}$ of binding buffer, $2 \mathrm{~mL}$ of Anexin V and PI and incubated for 10 minutes in the dark room, according to manufacturer's instruction, then the cells were analyzed with flowcytometer (FACS Calibur).

\section{Reactive Oxygen Species (ROS) Assay}

The $4 \mathrm{~T} 1$ cells in as much as $5 \times 10^{4}$ were seeded into each well of 24-well plates. Incubation cells for $24 \mathrm{~h}$ at an incubator temperature of $37^{\circ} \mathrm{C}$. Then, the cells were harvested in $500 \mu \mathrm{L}$ supplemented buffer (10\% FBS in 1x PBS). Furthermore, cell staining was conducted by adding $15 \mu \mathrm{M}$ Dichlorodihydrofluorescein diacetate (DCFDA) (3.75 $\mu \mathrm{L} 2 \mathrm{mM}$ DCFDA) (Abcam, Cambridge, UK) and incubated for 30 minutes in an incubator. The experiments was conducted as its describe on manufacturer's instruction. 4T1 cells were treated with concentrations of 40 and $60 \mu \mathrm{M}$ of PGB-0-So compounds and treatment with $1 \mu \mathrm{M}$ $\mathrm{H}_{2} \mathrm{O}_{2}$ as a positive control group. Incubation at $37^{\circ} \mathrm{C}$ for 3-4 $\mathrm{h}$ and analyzed by using a flowcytometer (FACS Calibur).

\section{RESULT}

\section{Cytotoxicity of Pentagamaboronon-0- Sorbitol (PGB-0-So)}

Single cytotoxic assay of PGB-0-So compound showed a dose-dependent inhibitory profile in 4T1 breast cancer cells (Figure 1). The 
A

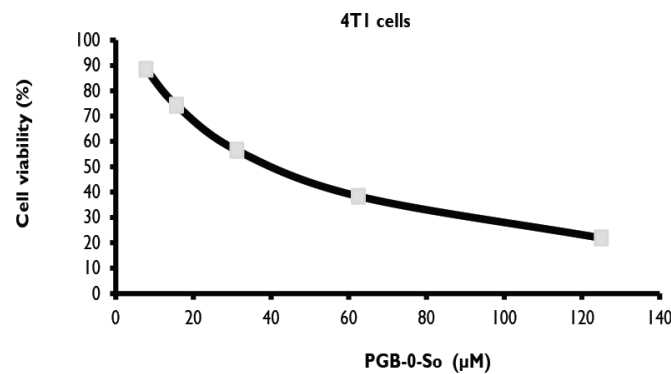

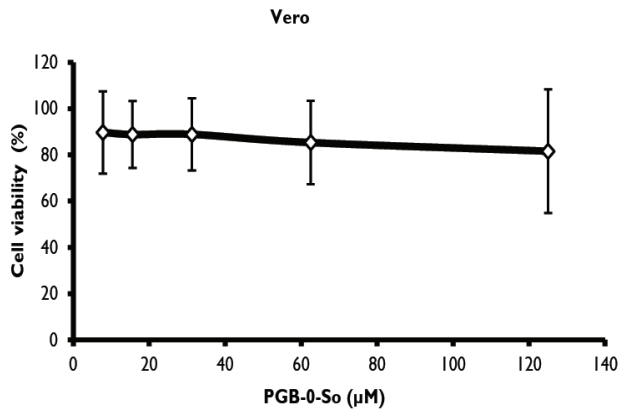

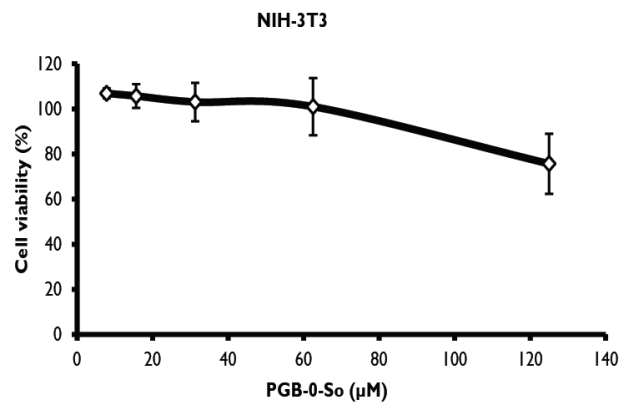

Figure 1. The Cytotoxicity Profile of PGB-0-So on Several Cell Lines. (A) The single cytotoxicity profile of PGB-0-So and conjugated sugar Sorbitol against 4T1 cell, (B) The single cytotoxicity profile of PGB-0-So against normal cell model Vero, $(C)$ The single cytotoxicity profile of against normal cell model NIH-3T3. Cells were treated with several concentration of PGB-0-So and Sorbitol (A) for $24 \mathrm{~h}$ then was analyzed by MTT assay. After regression analysis, the $\mathrm{IC}_{50}$ was measured by excel software $(P<0.01)$. All data were conducted on three independent experiment $(n=3)$. The single cytotoxicity test of PGB-0-So against triple negative breast cancer cell 4T1 cell showed the decrease of cell viability in dose-dependent manner, while the single cytotoxicity test of the conjugated sugar Sorbitol showed no toxic effect of Sorbitol agaist triple negative breast cancer cell 4T1 cell. PGB-0-So was also found non-toxic into two normal cell models, Vero and $\mathrm{NIH}-3 \mathrm{~T} 3$ cell line.

graph above shows that the higher the concentration of the PGB-0-So compound given, the lower the viability of $4 \mathrm{~T} 1$ breast cancer cells based on linear regression line interpolation. These data indicate that the PGB-0-So compound is toxic to 4T1 cells with a lethal concentration $\left(\mathrm{IC}_{50}\right)$ of $40 \mu \mathrm{M}$. Moreover, the $\mathrm{IC}_{50}$ value of PGB-0-So on Vero and NIH-3T3 were $>250$ and $>150$, respectively. According to the selectivity index, PGB-0-So is considered as selective toward cancer cells based on $\mathrm{SI}>3$, in which $>6$ in Vero, and $>3$ in NIH-3T3 cells.

Combination treatment of $1 / 2 \mathrm{IC}_{50}$ PGB-0-So compound and $1 / 2 \mathrm{IC}_{50}$ doxorubicin compound was able to reduce cell viability by up to $70 \%$ compared to the control group (Figure 2). Combination of
PGB-0-So with doxorubicin showed the synergistic effect of the PGB-0-So and doxorubicin causing the accumulation of cytotoxic effects between the two tested compounds compared with a single treatment.

\section{Effect of Pentagamaboronon-0-Sorbitol (PGB-0-So) in 4T1 Cell Cycle Modulation}

The treatment of PGB-0-So compounds on $4 \mathrm{~T} 1$ breast cancer cells for $24 \mathrm{~h}$ is known to be able to modulate the cell cycle and cause accumulation in the $\mathrm{S}$ phase of the cell cycle (Figure 3 ). The administration of PGB-0-So at concentrations of $40 \mu \mathrm{M}$ and $60 \mu \mathrm{M}$ showed an increase in cell accumulation in the $\mathrm{S}$ phase along with the increasing dose of PGB-0-So treatment given. 
A

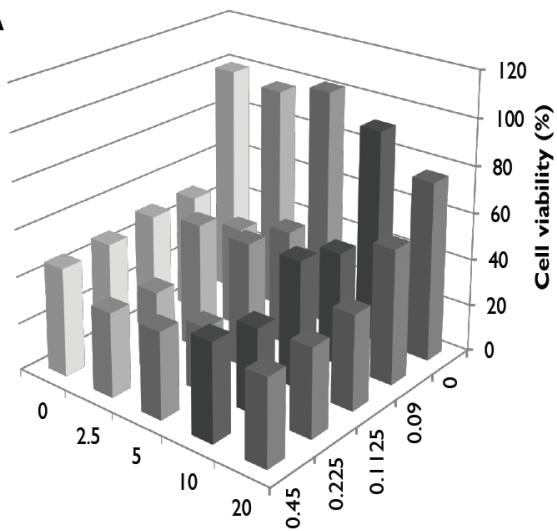

\begin{tabular}{|c|cccc|}
\hline \multicolumn{5}{|c|}{ Combination Index } \\
\hline $\begin{array}{c}\text { PGB-0-So } \\
(\mu \mathrm{M})\end{array}$ & 0.09 & 0.1125 & 0.225 & 0.45 \\
\cline { 2 - 5 } & \multicolumn{5}{|c|}{ Dox } \\
\hline 2.5 & 0.06 & 0.08 & 0.06 & 0.08 \\
5 & 0.14 & 0.15 & 0.1 & 0.13 \\
10 & 0.25 & 0.29 & 0.22 & 0.25 \\
20 & 0.6 & 0.44 & 0.43 & 0.44 \\
\hline
\end{tabular}

Figure 2. The cytotoxic effect of PGB-0-So in combination with Doxorubicin on TNBC 4T1 Cells. A. Cytotoxic profile of PGB-0-So in combination with Doxorubicin on 4T1 describing correlation between concentration and cell viability. B. Table of Combination Index of PGB-0-So with Doxorubicin on 4T1 cells. PGB-0-So performed synergic effect with Doxorubicin with combination index $<1$ against $4 \mathrm{~T} 1$ cells.

Treatment with $40 \mu \mathrm{M}$ PGB-0-So increased the S phase up to $11.92 \%$, meanwhile treatment with $60 \mu \mathrm{M}$ PGB-0-So increased the S phase by up to $12.59 \%$, both compared to control cells without treatment with PGB-0-So.

\section{Effect of Pentagamaboronon-0-Sorbitol (PGB-0-So) in Apoptosis Induction}

A single cytotoxic test of PGB-0-So compound showed the occurrence of cell death after incubation for $24 \mathrm{~h}$, then it is necessary to confirm which of the cell death pathway influenced by the compound. In this study, further apoptosis induction experiment was carried out using a flowcytometer. The data showed an increase in the induction of early stage and late stage apoptosis along with PGB-0-So treatment by the concentrations of 40 $\mu \mathrm{M}$ and $60 \mu \mathrm{M}$ (Figure 3). Treatment with PGB0 -So compounds generally induced an increase in 4T1 breast cancer cell death. The cell control group had a necrosis mortality rate of $1.4 \%$, an early phase of apoptosis of $3 \%$ and a late phase of apoptosis of $1.54 \%$. In the group treated with $40 \mu \mathrm{M}$ of PGB-0So compound, the percentage of necrosis mortality was detected $0.77 \%$; the early phase of apoptosis was $7.18 \%$ and the final phase of apoptosis was
$7 \%$. Meanwhile, in the group treated with $60 \mu \mathrm{M}$ of PGB-0-So compound, the percentage of necrosis mortality was detected $0.71 \%$; the initial phase of apoptosis was $9.41 \%$ and the final phase of apoptosis was $9.41 \%$.

\section{Reactive Oxidative Stress (ROS) Generation upon Pentagamaboronon-0-Sorbitol (PGB-0- So) Treatment}

The cytotoxicity and anti-proliferative activities of the PGB-0-So compound against 4T1 breast cancer cells can occur due to increased levels of ROS (Liou and Storz, 2010; Aggarwal, et al., 2019). In this study, the ROS intercellular level test was carried out using fluorescent compounds and cell permeable chemiluminescent probes, namely DCFDA which were then measured using flowcytometry. Based on the results below, it can be seen that incubation with the PGB-0-So compound on 4T1 breast cancer cells for $4 \mathrm{~h}$ was able to increase the ROS level, the higher the PGB-0-So treatment given the higher the ROS level detected. The treatment group with $40 \mu \mathrm{M}$ and $60 \mu \mathrm{M}$ PGB0 -So compound showed DCFDA mean fluorescence of 1.25 and 1.45 which was higher than the positive control group with $\mathrm{H}_{2} \mathrm{O}_{2}$. This result showed the 
role of PGB-0-So as a pro-oxidant that might able to increase cellular ROS level. Increasing the ROS level beyond the threshold can induce death in cancer cells (Atsumi, et al., 2007; Larasati, et al., 2018) .

\section{DISCUSSION}

This study aims to study one of the curcumin analogue compounds, namely PGB-0 which is reacted with PGB-0-So as a chemotherapy agent in triple negative $4 \mathrm{~T} 1$ breast cancer cells. The initial screening to determine the potential of PGB0 -So compounds in inhibiting the proliferative activity of highly metastatic 4T1 breast cancer cells was a cell cytotoxicity test using the MTT Assay chlorometric method. Single cytotoxic test of PGB0-So compound against 4T1 breast cancer cells showed a decrease in cell viability in accordance with the dose (dose-dependent manner) with an $\mathrm{IC}_{50}$ value of $40 \mu \mathrm{M}$. Meanwhile, sorbitol, which in this study was reacted with the PGB-0 compound to increase the solubility of the compound, did not show cytotoxicity effects on 4T1 breast cancer cells. It showed that the cytotoxic potential exerted by PGB-0-So compound is not an accumulation of cytotoxic effects between the two compounds being reacted. Based on the results of testing the cytotoxicity activity of PGB-0-So, compound's complexation with sorbitol not only improved its solubility but also its cytotoxic properties compared to previous studies. Utomo, et al., 2017 reported that PGB-0 inhibited MCF-7/HER2 cell growth with the $\mathrm{IC}_{50}$ value of $270 \mu \mathrm{M}$ while Kusumastuti, et al., 2019 reported that PGB-0 showed cytotoxic effect against 4T1 cell with the $\mathrm{IC}_{50}$ value of $294 \mu \mathrm{M}$. This result explained that complexation with sorbitol significantly increased PGB-0 cytotoxicity against breast cancer cells. Nevertheless further research is needed regarding the stability and solubility of this compounds. In addition, in the development of PGB-0-So as BNCT agents, further testing regarding the transportation and accumulation of the compound in cells are importantly needed.

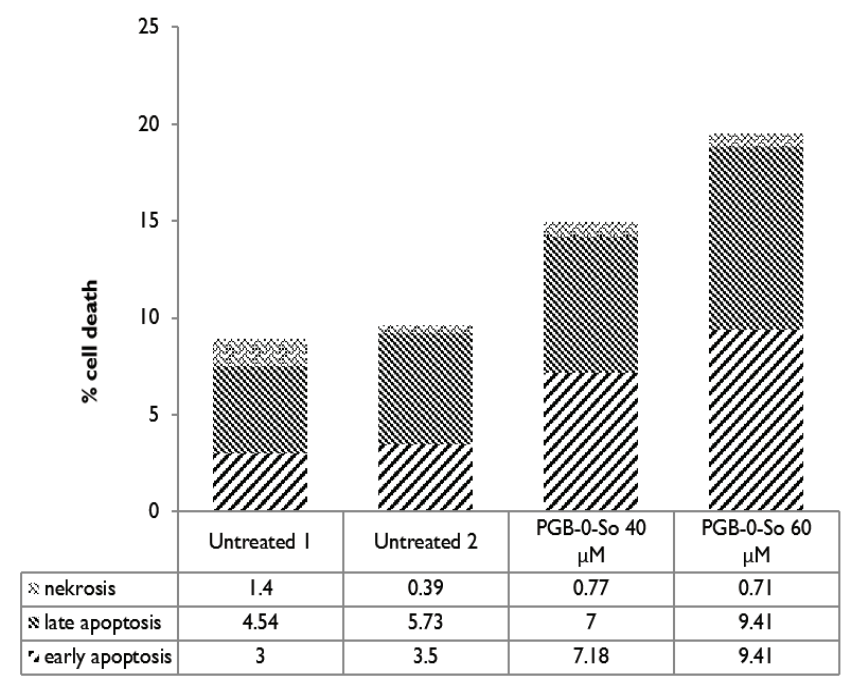

Figure 3. The Effect of PGB-0-So on Cell Cycle Modulation and Apoptosis Induction against TNBC 4T1 cell. Cells were treated with $40 \mu \mathrm{M}$ and $60 \mu \mathrm{M}$ of PGB-0-So against $4 \mathrm{~T} 1$ cells for $24 \mathrm{~h}$. The cells then harvested and conducted DNA content analysis by flow cytometry with PI staining for cell cycle modulation analysis and with Annexin-V and PI for apoptosis induction analysis. Cell cycle profiles in the sub-G1, G1, S, and $\mathrm{G} 2 / \mathrm{M}$ of the cells and the quantification of cell distribution on the each cell cycle phase. PGB-0-So revealed S phase arrest as well as apoptosis induction at the concentration $40 \mu \mathrm{M}$. 
Cytotoxic testing of the combination of PGB-0-So compounds with doxorubicin showed a synergistic effect of the two compounds on 4T1 breast cancer cells. Previous studies reported that at certain concentrations, the combination of curcumin and the chemotherapy agent doxorubicin has a synergistic effect and is able to influence down regulation of the expression of several genes including: c-myc, Bcl-XL, c-IAP-2, NAIP, XIAP which play an important role in maintaining the ability to proliferate cancer cells (Notarbartolo, et al., 2005; Limtrakul, 2007). In this study, the sublethal dose of PGB-0-So and doxorubicin were found to be able to reduce the viability of 4T1 breast cancer cells by up to $70 \%$, this is in line with previous studies which stated that the synergistic effect of the combination of curcumin analogue compounds with doxorubicin was obtained at sub $\mathrm{IC}_{50}$ doses (Putri, et al., 2016; Kusumastuti, et al., 2019). It indicates that PGB-0-So can be combined with doxorubicin as a co-chemotherapy compound with a smaller chemotherapy dose.

The findings of the compound cytotoxicity test then can be confirmed through the cell cycle modulation test using the flowcytometry method. The single treatment of the PGB-0-So compound is able to modulate the cell cycle through induction arrest in the synthesis phase (S phase) of the cell cycle. They are in line with previous research which shows that the DBBAC or PGB-0 compound causes S-phase arrest which is most likely due to DNA damage (Kusumastuti, et al., 2019). DNA damage results in the accumulation of broken DNA double strands which is induced by topoisomerase I inhibitor (SN38), this event has implications for arrest in the $\mathrm{S}$ phase of the cell cycle. Cancer cells that did not undergo arrest in the G1 phase after treatment with flavopiridol showed growth inhibition activity in the S phase which could then experience cell death (apoptosis) earlier and more efficient than cells that undergo arrest in the G1 phase after treatment with drug compounds. Failure of G1 arrest due to the presence of Cyclin dependent kinase (Cdk) inhibitors increases the apoptotic response of cells (Doumont, et al., 2005). A further test to confirm the results of cytotoxic tests and the results of cell cycle modulation tests was apoptosis induction test. In apoptosis testing with flowcytometry, we need to identify membrane conditions and cell genetic material $24 \mathrm{~h}$ after treatment. The initial phase of apoptosis is characterized by translocation of phosphatidylserine (PS) on the inner cell membrane to the outer membrane. This displacement causes PS to face the outside of the cell so that it is able to

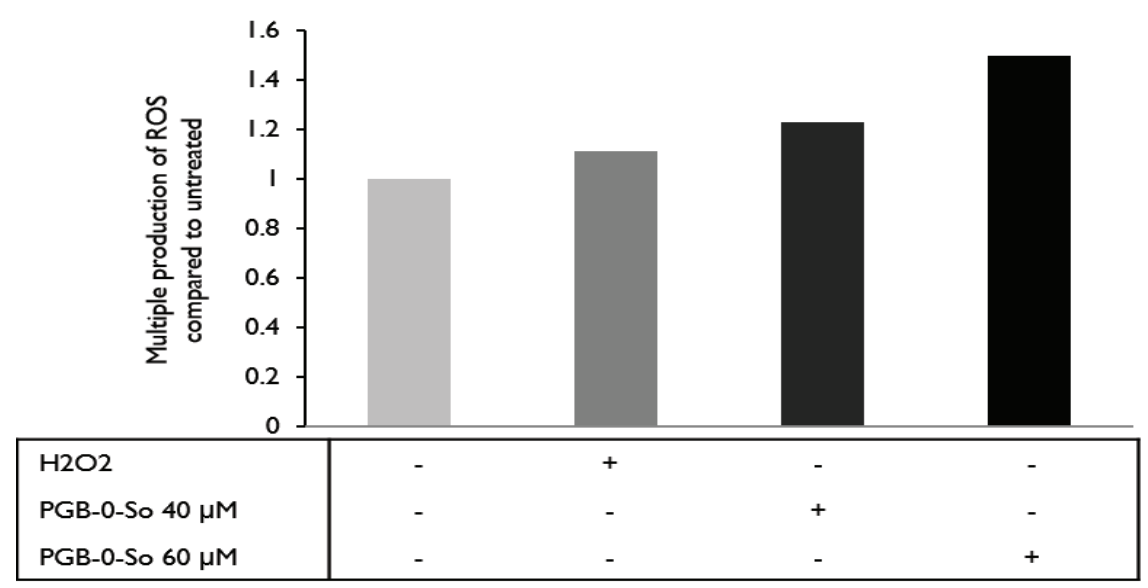

Figure 4. PGB-0-So modulated the ROS level of TNBC 4T1 Cells. Cells were stained with DCFDA then treated with two different concentrations PGB-0-So for $4 \mathrm{~h}$ and then subjected to FACS flowcytometry. X-axis, the cellular ROS level; Y-axis, the relative cell count. ROS level elevated after treatment with PGB-0-So in dose-dependent manner. 
interact with the external proteins of the cell. In this test, detection of the presence of PS was carried out using Annexin V (in the form of $\mathrm{Ca} 2+$-dependent phospholipid-binding protein) which is a specific protein and is able to strongly interact with the PS residue. The detection of PS in cells indicates an early phase of cell death in the apoptotic pathway (Elmore, 2007). The detection of apoptotic events is also carried out with PI which is able to intercalate with DNA so that it can show the DNA content of cells. The final phase of apoptosis is characterized by the occurrence of DNA fragmentation followed by loss of nuclear DNA, which can be detected using a PI. Viable cells will have low Annexin V and PI intensities (Vermes, et al., 1995; Riccardi and Nicoletti, 2006).

Incubation with PGB-0-So compound showed the ability of the compound to induce an increase in the percentage of cell death in the apoptotic pathway. The mechanism of apoptosis induction in $4 \mathrm{~T} 1$ breast cancer cells is most likely to occur via the p53-independent mitochondrial pathway (intrinsic pathway). This is because triple negative breast cancer cells, such as 4T1 cells used in this study, have mutations in the $\mathrm{p} 53$ protein which play an important role in the induction of apoptosis in the extrinsic pathway (Yerlikaya, et al., 2012). Incubation with the PGB-0-So compound is possibly affected depolarization of the mitochondrial membrane so that cytochrome $\mathrm{C}$ is released from the membrane, cytochrome $\mathrm{C}$ then activates caspase 9 which can induce activation of other caspases (caspase 3). Activation of caspase protein then induces activation of endonuclease and proteases which play a role in the degradation of chromosomal DNA, nuclear lamina and cytoskeletal proteins until apoptosis occurs (Tsang, et al., 2003; Elmore, 2007; Karp, 2008).

To understand more deeply about the cytotoxic and anti-proliferative effects of PGB-0So compounds on $4 \mathrm{~T} 1$ breast cancer cells, as well as the mechanisms for inducing cell death that are likely to occur, in this study, intracellular ROS levels were tested in 4T1 breast cancer cells after incubation with compound PGB-0-So for about $4 \mathrm{~h}$. In this study, it can be seen that there was an increase in ROS levels in cells incubated with the PGB-0-So compound compared to the untreated control group (as a negative control group) and the group induced by addition of $\mathrm{H}_{2} \mathrm{O}_{2}$ (as a positive control group). ROS can be in the form of ions or radical molecules with one single electron in the outer layer of the electron layer, so it has a very high reactivity. In normal conditions, ROS is very tightly guarded by the presence of antioxidants and repair mechanisms so that it does not cause oxidative stress (Manda, et al., 2009). Elevated levels of ROS beyond the normal threshold are known to cause cancer cell death. Previous studies reported that curcumin has the ability as a pro-oxidant agent capable of inducing increased production of ROS in cells (Atsumi, Tonosaki and Fujisawa, 2007; Larasati, et al., 2018). In cells ROS acts as a messanger in the signal transduction pathway, influences protein phosphatase and plays an important role in the regulation of transcription factors (Chiarugi, et al., 2003; Torres, et al., 2003; Zhang, et al., 2004). ROS can affect the activation of several important genes for transcription factors, including the c-fos, c-jun, ATF, JDP and NF-kB gene families (Manda, et al., 2009). In addition, high production of ROS can induce apoptosis by influencing the expression and translocation of Bax to mitochondria, causing mitochondrial damage, release of cytochrome c, activation of caspase 3 resulting in apoptosis (Dumay, et al., 2006; Susnowa, et al., 2009; RedzaDutordoir, et al., 2016).

\section{CONCLUSION}

The PGB-So treatment against TNBC cell 4T1 was able to modulate cell cycle and induce apoptosis especially through the elevation of the cellular ROS level. These findings suggest that PGB-0-So is potential as an anticancer agent. 


\section{ACKNOWLEDGEMENTS}

This Research is supported by grants from Penelitian Dasar Unggulan Perguruan Tinggi (PDUPT) 2020 contract No. 1668/UN1/ DITLIT/DIT-LIT/PT/2020, Indonesian Ministry of Research, Technology and Higher Education.

\section{REFERENCES}

Aggarwal, V., Tuli, H.S., Varol, A., Thakral, F. Yerer, M.B., Sak, K., et al., 2019, Role of Reactive Oxygen Species in Cancer Progression: Molecular Mechanisms and Recent Advancements, Biomolecules, 9(11), 735.

Amalina, N.D., Nurhayati, I.P. and Meiyanto, E., 2017, Doxorubicin Induces Lamellipodia Formation and Cell Migration, Indonesian Journal of Cancer Chemoprevention, 8(2), 61-67.

Atsumi, T., Tonosaki, K. and Fujisawa, S., 2007, Comparative cytotoxicity and ROS generation by curcumin and tetrahydrocurcumin following visible-light irradiation or treatment with horseradish peroxidase, Anticancer Research, 27(1A), 363-371.

Chen, M.-L., Sadrieh, N. and Yu, L., 2013, Impact of Osmotically Active Excipients on Bioavailability and Bioequivalence of BCS Class III Drugs, The AAPS Journal, 15(4), 1043-1050.

Chiarugi, P. and Cirri, P., 2003, Redox regulation of protein tyrosine phosphatases during receptor tyrosine kinase signal transduction, Trends in Biochemical Sciences, 28(9), 509-514.

Covarrubias, L., Hernandez-Garcia, D., Schnabel, D. and Salas-Vidal, E., 2008, Function of reactive oxygen species during animal development: Passive or active?, Developmental Biology, 320(1), 1-11.

Dash, R.P., Srinivas, N.R. and Babu, R.J., 2019, Use of sorbitol as pharmaceutical excipient in the present day formulations-issues and challenges for drug absorption and bioavailability, Drug Development and Industrial Pharmacy, 45(9),
1421-1429.

Dawood, S., 2010, Triple-negative breast cancer: epidemiology and management options, Drugs, 70(17), 2247-2258.

Dayem, A.A., Hossain, M.K., Lee, S.B., Kim, K., Saha, S., Yang, G-M., et al., 2017, The Role of Reactive Oxygen Species (ROS) in the Biological Activities of Metallic Nanoparticles, International Journal of Molecular Sciences, 18(1), 120.

Doumont, G., Martoriati, A., Beekman, C., Bogaerts, S., Mee, P. J., Bureau, F., Colombo, E., Alcalay, M., Bellefroid, E., Marchesi, F., Scanziani, E., Pelicci, P. G., and Marine, J., 2005, G1 checkpoint failure and increased tumor susceptibility in mice lacking the novel p53 target Ptprv, The EMBO Journal, 24(17), 3093-3103.

Dumay, A., Rincheval, V., Trotot, P., Mignotte, B. and Vayssière, J., 2006, The superoxide dismutase inhibitor diethyldithiocarbamate has antagonistic effects on apoptosis by triggering both cytochrome c release and caspase inhibition, Free Radical Biology \& Medicine, 40(8) 1377-1390.

Elmore, S., 2007, Apoptosis: A Review of Programmed Cell Death, Toxicologic pathology, 35(4), 495516.

Ferlay, J., Soerjomataram, I., Dikshit, R., Eser, S., Mathers, C., Rebelo, M., et al., 2015, Cancer incidence and mortality worldwide: Sources, methodsand major patterns in GLOBOCAN 2012, International Journal of Cancer, 136(5), 359386.

He, L., He, T., Farrar, S., Ji, L., Liu, T. and Ma, X., 2017, Antioxidants Maintain Cellular Redox Homeostasis by Elimination of Reactive Oxygen Species, Cellular Physiology and Biochemistry, 44(2), 532-553.

Karp, G., 2008, Cell and Molecular Biology : concept and experiment, in. John-Willey and Sons Inc. Hoboken., p. 654.

Kusumastuti, R., Utomo, R.Y., Khumaira, A., Putri, H., Jenie, R.I. and Meiyanto, E., 2019, Pentagamaboronon-0 increased cytotoxicity 
of and inhibited metastasis induction by doxorubicin in breast cancer cells, Journal of Applied Pharmaceutical Science, 9(06), 43-51.

Larasati, Y.A., Yoneda-Kato, N., Nakamae, I., Yokoyama, T., Meiyanto, E. and Kato, J-y., 2018, Curcumin targets multiple enzymes involved in the ROS metabolic pathway to suppress tumor cell growth, Scientific Reports, 8, 2039.

Lee, Y.T., 1983, Breast carcinoma: pattern of metastasis at autopsy, J. Surg. Oncol., 3(23), 175-180.

Limtrakul, P. , 2007, Curcumin as Chemosentizer, in Aggarwal, B.B., Surh, Y.-J., and Shishodia, S. (eds) The Molecular Targets and Therapeutic Uses of Curcumin in Health and Disease. Boston, MA: Springer US (Advances in Experimental Medicine and Biology), 269-300.

Liou, G.-Y. and Storz, P., 2010, Reactive oxygen species in cancer, Free radical research, 44(5), 479-496.

Nechifor, M.T., Neagu, T-M. and Manda, G., 2009, Reactive Oxygen Species, Cancer and AntiCancer Therapies, Current Chemical Biology, 3(1), 22-46.

Meiyanto, E., Putri. D.D.P., Susidarti, R.A., Murwanti, R., Sardjiman, Fitriasari, A., et al., 2014, Curcumin and its Analogues (PGV-0 and PGV-1) Enhance Sensitivity of Resistant MCF-7 Cells to Doxorubicin through Inhibition of HER2 and NFkB Activation, Asian Pacific Journal of Cancer Prevention, 15(1), 179-184.

Mendes, D., Alves, C., Afonso, N., Cardoso, F., PassosCoelho, J.L., Costa, L., et al., 2015, The benefit of HER2-targeted therapies on overall survival of patients with metastatic HER2-positive breast cancer - a systematic review, Breast Cancer Research, 17(1), 140.

Mosmann, T., 1983, Rapid colorimetric assay for cellular growth and survival: application to proliferation and cytotoxicity assays, Journal of Immunological Methods, 65(1-2), 55-63.

Notarbartolo, M., Poma, P., Perri, D., Dusonchet, L., Cervello, M., D’Alessandro, N., 2005, Antitumor effects of curcumin, alone or in combination with cisplatin or doxorubicin, on human hepatic cancer cells. Analysis of their possible relationship to changes in NF-kB activation levels and in IAP gene expression, Cancer Letters, 224(1), 53-65.

Putri, H., Jenie, R.I., Handayani, S., Kastian, R.F. and Meiyanto, E., 2016, Combination of Potassium Pentagamavunon-0 and Doxorubicin Induces Apoptosis and Cell Cycle Arrest and Inhibits Metastasis in Breast Cancer Cells, Asian Pacific journal of cancer prevention, 17(5), 2683-2688.

Qodria, L., Hairunisa, I., Utomo, R.Y., Hermawan, A. and Meiyanto, E., 2018, Anti-metastatic Activity of Curcumin Analog Pentagamaboronon-0Sorbitol Against HER2-overexpressed MCF-7 Breast Cancer Cells, Indonesian Journal of Cancer Chemoprevention, 9(3), 118-125.

Ramadani, R.D., Utomo, R.Y., Hermawan, A. and Meiyanto, E., 2018, Curcumin Analog Pentagamaboronon-0-Sorbitol Inhibits Cell Migration Activity of Triple Negative Breast Cancer Cell Line, Indonesian Journal of Cancer Chemoprevention, 9(3), 126-133.

Redig, A.J. and McAllister, S.S., 2013, Breast cancer as a systemic disease: a view of metastasis, Journal of internal medicine, 274(2), 113-126.

Redza-Dutordoir, M. and Averill-Bates, D.A., 2016, Activation of apoptosis signalling pathways by reactive oxygen species, Biochimica et Biophysica Acta, 1863(12), 2977- 2992.

Reynolds, C.P. and Maurer, B.J., 2005, Evaluating response to antineoplastic drug combinations in tissue culture models, Methods Mol Med, 110, 173- 183.

Riccardi, C. and Nicoletti, I., 2006, Analysis of apoptosis by propidium iodide staining and flow cytometry, Nature Protocols, 1(3), 1458-1461.

Schattenberg, J.M. and Czaja, M. J., 2014, Regulation of the effects of CYP2E1-induced oxidative stress by JNK signaling, Redox Biology, 3, 7-15.

Simon, H.-U., Haj-Yehia, A. and Levi-Schaffer, F., 2000 , Role of reactive oxygen species (ROS) in 
apoptosis induction, Apoptosis, 5(5), 415-418. Son, Y., Cheong, Y-K., Kim, N-H., Chung, H-T., Kang, D.G. and Pae, H-O., 2011, Mitogen-Activated Protein Kinases and Reactive Oxygen Species: How Can ROS Activate MAPK Pathways?, Journal of Signal Transduction, 2011, 792639.

Susnow, N., Zheng, L., Margineantu, D., and Hockenbery, D.M., 2009. Bcl-2 family proteins as regulators of oxidative stress, Semin Cancer Biol., 19(1): 42-49.

Torres, M. and Forman, H.J., 2003, Redox signaling and the MAP kinase pathways, BioFactors, 17(14), 287-296.

Tsang, W.P., Chau, S.P.Y., Kong, S.K., Fung, K.P. and Kwok, T.T., 2003, Reactive oxygen species mediate doxorubicin induced $\mathrm{p} 53$-independent apoptosis, Life Sciences, 73(16), 2047-2058.

Utomo, R.Y., Putri, H., Pudjono, Susidarti, R.A., Jenie, R.I. and Meiyanto, E., 2017, Synthesis and Cytotoxic Activity of 2,5-BIS(4-Boronic Acid)Benzylidine Cyclopentanone on HER2 Overexpressed-Cancer Cells, Indonesian Journal of Pharmacy, 28(2), 74-81.

Vermes, I., Haanen, C., Steffens-Nakken, H. and Reutelingsperger, C., 1995, A novel assay for apoptosis Flow cytometric detection of phosphatidylserine expression on early apoptotic cells using fluorescein labelled Annexin V, Journal of Immunological Methods, 184(1), 39-51.

Watanabe, T., Hattori, Y., Ohta, Y., Ishimura, M., Nakagawa, Y., Sanada, Y., et al., 2016, Comparison of the pharmacokinetics between L-BPA and L-FBPA using the same administration dose and protocol: a validation study for the theranostic approach using [18F]-L-FBPA positron emission tomography in boron neutron capture therapy, BMC cancer, 16(1), 859.

Xiao, W., Zheng, S., Liu, P., Zou, Y., Xie, X., Yu, P., et al., 2018, Risk factors and survival outcomes in patients with breast cancer and lung metastasis: a population- based study, Cancer Medicine, 3(7), 922-930.

Yerlikaya, A., Okur, E. and Ulukaya, E., 2012, The p53-independent induction of apoptosis in breast cancer cells in response to proteasome inhibitor bortezomib, Tumour Biology, 33(5), 1385-1392.

Zhang, Y. and Chen, F., 2004, Reactive oxygen species (ROS), troublemakers between nuclear factorkappaB (NF-kappaB) and c-Jun NH(2)-terminal kinase (JNK), Cancer Research, 64(6), 19021905. 